\title{
Essay
}

\section{Genfortællingens kraft}

Hanne Bess Boelsbjerg

$h b b @ s o c . k u . d k$

Interacting Minds, AU

Boelsbjerg, Hanne Bess. (2020). Genfortællingens kraft. Tidsskrift for Forskning $i$ Sygdom og Samfund nr 33, 131-138

I min forskning omkring uhelbredeligt syge kræftpatienters tro fordybede jeg mig i deres livsverden og ønskede at formidle det, jeg fandt frem til, gennem 'empiriske fortællinger' (Boelsbjerg, 2017). Jeg gik fænomenologisk til værks i selve udforskningen af tro og fokuserede på at følge kræftpatienter med kristen eller muslimsk trosbaggrund over længere tid, samt at inddrage deres pårørende og en professionel omsorgsyder. Undersøgelsen havde til hensigt at være med til at kvalificere den del af den palliative indsats, der arbejder med at imødekomme eksistentielle, spirituelle og religiøse behov, der kan optræde i tiden op mod døden. Derfor tænkte jeg, at det var hensigtsmæssigt at benytte mig af fortællinger som led i at få sundhedsprofessionelle til at indleve sig i en livsverden, som kunne ligge fjernt fra deres egen. Samtidigt ville jeg gerne fremme en generel forståelse for indlevelse som en erkendelsesmulighed, der kan informere sundhedsfaglig praksis. Samtidigt krævede dette greb, at jeg måtte argumentere for, hvordan det at anvende fortællinger som videnskabelig formidlingsform kunne forsvares. Det gjorde det vigtigt at kunne vurdere disse fortællingers troværdighed i form af gyldighed og udsigelseskraft.

For at min undersøgelse opfattes som troværdig i en antropologisk sammenhæng, må jeg som forsker fremvise refleksivitet og gennemsigtighed i alle dele af undersøgelsens faser. Det gælder fra valg af problemstilling og metoder, til udførelse af empiriindsamling og analyse samt brug af teoretiske perspektiver og ikke mindst formidling af den frembragte forståelse (Hastrup et al., 2011). Undersøgel- 
sens validitet er selve fundamentet for, at de empiriske fortællinger fremstå som gyldige. Men selvom jeg redegør for refleksioner over de valg, der knytter sig til at anvende fortælling som formidlingsstrategi, fører det ikke frem til en vurdering af, om jeg har evnet at tage tilstrækkeligt hensyn til de forskellige perspektiver, der fremkommer i det empiriske materiale.

For at besvare det spørgsmål har jeg efter undersøgelsens afslutning valgt at vende tilbage til en af de informanter, der havde medvirket i undersøgelsen som pårørende for at få respons på en del af den fortælling, han havde kendskab til. Eksperimentet foregik i forlængelse af, at jeg arbejdede på en artikel, hvor jeg havde brug for at validere betydningen af en af de begivenheder, jeg beskrev. Jeg greb chancen for at anvende en inkluderende form for valideringspraksis, der beror på 'genfortælling'. Ved at bede om respons på et element i en af de empiriske fortællinger, gør jeg denne informant til 'medfortæller'. For i kraft af hans respons forandrer fortællingen sig også.

\section{At fortælle om stigma}

Som konsekvens af at have fulgt de kræftpatienter, som undersøgelsen drejede sig om, så tæt, som situationen tillod, og at jeg involverede både pårørende og professionelle omsorgsydere til at udtrykke sig om den berørte, fik jeg skabt en mangfoldighed af perspektiver, der inkluderede mit eget. I sammensmeltningen af disse perspektiver til en samlet fortælling, fremhævede jeg et tema eller en problematik, der måtte have interesse for forskningsområdet eller den sundhedsfaglige praksis. Spørgsmålet er, om denne vinkling fremstår nuanceret og rummelig nok til at blive genkendt som relevant af en af de direkte involverede.

Denne overvejelse bliver reaktualiseret i en situation, hvor jeg som nævnt er i gang med en artikel. Her laver jeg et uddrag af to af de empiriske fortællinger for at bringe dem i spil, så de matcher tidsskriftets tema. Fortællingerne omhandler de to deltagere, som jeg får lov at følge tættest på, hvorved jeg opnår et dybt kendskab til deres familieforhold, livshistorie og trosforhold. Det ender også med at jeg deltager til begges begravelse eller mindehøjtidelighed. Den ene af disse to, lad os kalde hende Mary, er af afrikansk oprindelse. Hun bor i et kvarter, som betegnes som 'ghetto'. Mary bor alene, og første gang vi ses i hendes lejlighed, tænker jeg, at hun har et meget sparsomt netværk og er at betragte som 'socialt udsat'. Hun har nemlig ingen billeder af familie eller venner hængende på væggene og omtaler heller ikke nogen som specielt nære. Jeg bliver dog stærkt korrigeret i det billede, 
jeg får tegnet af hendes liv, efterhånden som jeg lærer hende at kende. For hun har en ven, der stort set hjælper hende med alt. Otto kan vi kalde ham. Otto og Mary har lært hinanden at kende tilbage i 70'erne, hvor Mary kom til Danmark. De mødtes til en fest i en venskabsforening, og Otto blev så inspireret af sit venskab med Mary, at han endte med at kvalificere sig til at kunne lede udviklingsprojekter for det, man dengang kaldte ulande.

I forbindelse med artiklen ønsker jeg at beskrive den form for stigmatisering, der kan finde sted, når en palliativ patient ikke ønsker at udøve de fysiske aktiviteter, der er så meget fokus på inden for sundhedsområdet. Mary udgør en oplagt case, da hun nægter at følge de sundhedsprofessionelles målsætninger om at optimere sine dagligdagsaktiviteter. Hun fremstår i stedet som fysisk inaktiv og ude af stand til at sætte sig et mål og fuldføre det. Jeg fremstiller de reaktioner, de sundheds-professionelle har på det, de opfatter som manglende samarbejde, og sætter det i samspil med det stigma, som består i at have en krop, der er i forfald. Dernæst vil jeg sætte det i forhold til tidligere oplevelser af stigma. Det er her, at det, jeg inddrager i fortællingen, kan forstærke det perspektiv, jeg allerede har valgt at anlægge eller blive suppleret af en anden vinkling.

For at beskrive hendes oplevelse af stigma, trækker jeg på en episode, som Mary delte med mig. I det boligkompleks, som hendes lejlighed lå i, var der mange andre med anden etnisk herkomst. De fleste af hendes naboer var muslimer. Hun selv var kristen. Og sort. Og havde oplevet at børnene, der legede i gården, havde kastet sten op på hendes altan. I forbindelse med at beskrive Marys tidligere erfaringer med stigma, mente jeg, at det var et sted, hvor det blev tydeligt, at disse sten var en reaktion på, at hun var af en anden etnisk herkomst og med et andet religiøst ståsted end de fleste af børnene. Samtidigt eksisterer der et andet (moralsk) stigma, som Mary havde båret i sit liv - for hun havde drukket meget i en periode af sit liv. Og ude på altanen placerede hun sine tomme ølflasker. For at vise sammensmeltningen af de forskellige former for stigma, vurderer jeg, at det er en vigtig del af fortællingen, at der står en ølkasse på altanen.

I min iver efter at få valideret min vinkling af fortællingen kontakter jeg hendes ven Otto, som jeg stadig er i kontakt med. Jeg forklarer ham, at jeg har brug for at få bekræftet episoden, da jeg ikke længere er fuldstændig sikker på, hvordan det hænger sammen med stenkastene og selve oplevelsen af at blive stigmatiseret. Jeg har sendt ham det aktuelle uddrag af fortællingen, så han kan bekræfte min beskrivelse af, hvordan det er at bo et sted, hvor man bliver bedømt på sin etnicitet og religion som noget, der udløser stigmatiserende adfærd. Jo, svarer Otto mig, det er sådan, at Mary på et tidspunkt bliver spurgt af nogle børn fra gården, 
om hun er muslim, hvortil hun svarer, at hun er kristen. Så begynder de at kaste sten efter hende. Og det sker flere gange. Hun forstod det ikke helt, fordi hun i sit hjemland ikke havde oplevet den form for konflikter mellem kristne og muslimske trosfæller. Otto siger, at hun havde mange venner hjemmefra, der er muslimer, og det har aldrig været et problem. Men det med at kaste sten op på altanen, det var et alment problem blandt beboerne i ejendommen. Det var altså ikke kun hende, der var udsat for det. Det var måske forbundet med, at børnene vidste, at hun boede der, overvejer han. Viceværten havde ikke kunne gøre noget ved det. Og politiet tog sig ikke af det, fortæller han. I det jeg har sendt ham, stod det med ølkassen også beskrevet. Otto forstår ikke helt, hvorfor det skal være med. For rækværket på altanen er så højt, at man umuligt kan se kassen nede fra gården. På den måde synes han ikke, den hører til. Desuden var Mary flittig til at få afleveret sine tomme flasker, så de ikke hobede sig op. Dermed mener han ikke, at altanen signalerede, at hun havde et alkoholproblem.

Det med alkoholen var i det hele taget noget, man havde svært ved at finde en fælles fortælling om i familien, hvad anden forskning om alkoholmisbrug blandt kræftpatienter bekræfter (Glasdam \& Øye, 2013). Det blev tydeligt efter Marys død, hvor der blev holdt en 'solnedgangsfest' for hende. I den forbindelse blev forskellige familiemedlemmer og venner opfordret til at fortælle om Mary, som de huskede hende. På sin mors opfordring gav en af hendes niecer sig til at beskrive Mary. Jo, hendes moster var en glad kvinde, altid med en øl i hånden og en cigaretstump i munden. Otto, der selv vendte tilbage til episoden, var rasende! Hvad var det for en utaknemmelig måde at beskrive Mary på? Dels holdt hun op med at have et alkoholmisbrug for flere år siden og drak kun ved festlige lejligheder, og hun stoppede med at ryge, da hun fik konstateret kræft! Det var slet ikke et passende billede og beskrev intet af alt det, som hele hendes familie havde at være taknemmelig over ved at blive familiesammenført med Mary, hvilket var årsagen til, at de overhovedet befandt sig i Danmark.

\section{Fortælling som forhandling af forståelse}

At bruge fortællingen som ramme for at skabe forståelse af stigmatisering risikerer at udløse en følelse af at blive udstillet eller fremstillet på en forkert eller unuanceret facon. Otto gjorde modstand mod fortællingen, som udtryk for, at den ikke spejlede hans opfattelse af, hvad der var vigtigt at tillægge betydning; at Mary ikke blev udsat for chikane fra gårdens børn pga. tomme ølflasker, men pga. 
sit religiøse tilhørsforhold, og at hun fortjente respekt fra sine familiemedlemmer fremfor at anvende hendes mindehøjtidelighed til at få hende til at fremstå som en fordrukken kvinde. Selvom hun havde oplevet at blive afvist eller behandlet dårligt pga. af de former for stigma, hun blev tildelt, så protesterer Otto gentagende gange imod, at det er sådan, at fortællingen om Mary skal lyde. Efter at have eksperimenteret med at inddrage en medfortæller og have modtaget Ottos respons, bliver jeg i tvivl om, hvorvidt det er en metode, der direkte kan anvendes som en mere sikker form for validering af troværdige fortællinger. For nu må jeg spørge mig selv, om jeg bør omskrive fortællingen, så den i højere grad afspejler de holdninger, som Otto har. Der er trods alt tale om et menneske, der har haft længere tid til at danne sig indtryk af Mary. Hvis jeg fastholder den udformede fortælling, er den så mere velegnet til at få Mary til at fremstå som stigmatiseret? Og vil den vinkling i så fald blive mindre valid, nu hvor Otto er kommet med sine korrektioner? Jeg kan jo beholde den tomme ølkasse som et symbol på, at den problematik stadig præger, hvordan andre opfatter hende - ligesom niecen fremhæver cigaretten og øllen som hendes væsentligste karaktertræk under mindefesten. Fortælling er jo udtryk for en gendigtning af det hændte, så selvom børnene ikke kunne se ølkassen, så stod den der jo, fordi hun havde brugt den til tomme flasker.

I diskussionen med mig selv, om hvordan jeg sikrer troværdige fortællinger ved at inddrage andre som medfortællere, indser jeg, at selvom vi er flere om at fortælle, forbliver det et udsnit af den samlede fortælling. Og den udvidede fortæller-status gør det ikke nødvendigvis til en mere 'rigtig' fortælling, snarere til en mere kompleks fremstilling, som bygger på en forhandling af hvilket perspektiv, der skal have lov til at træde i forgrunden. At opdage, at det at fortælle er udtryk for en forhandling med sin virkelighedsforståelse, er blevet gjort før, bl.a. af sociolog Margaretha Järvinen i forbindelse med at interviewe alkoholikere om deres misbrug (Järvinen, 2000). Hun anskueliggør, hvordan fortællinger i selve interviewsituationen signalerer, at der er tale om en fælles konstruktion af en virkelighedsforståelse, som samtidig med stilles til forhandling. Den form for kompleksitet i fremstillingen af, hvordan virkeligheden tager sig ud, kan med held indfanges af fortællingen.

\section{At forstå gennem fortællinger}

Brugen af en narrativ tilgang er efterhånden veletableret inden for den medicinske antropologi. Den har ligeledes vundet indpas i den medicinske tradition, hvor man 
i visse sammenhænge anvender kunst og litteratur for at træne sundhedsprofessionelle $\mathrm{i}$ at indleve sig i patienters livsverden (Charon et al., 2017; Juhl Rasmussen, 2017). Inden for den antropologiske tradition har det bl.a. været den amerikanske antropolog Cheryl Mattingly, der har medvirket til at skabe opmærksomhed på fortælling som en narrativ struktur, der bør vises særskilt interesse (Mattingly, 2001) ${ }^{1}$. Fortællingens magi består $i$, at den kan formidle noget ukendt gennem det velkendte. Det velkendte bliver etableret ved at anvende beskrivelser af personer, omgivelser og handlinger, så de fremstår som en sammenhængende helhed, hvilket slægter ens egne oplevelser på. Det skaber forudsætningen for en indlevelse i ukendte erfaringer, som indrammes af fortællingen som en meningsgivende struktur. Det kan man som kvalitativ forsker med fordel gøre brug af, da det at fortælle medvirker til at skabe en mere umiddelbar forståelse for det fænomen, der undersøges, hvorved fortællinger kan tilskrives et erkendelsesmæssigt potentiale. Men det ovenstående eksempel viser, at det ikke nødvendigvis er så enkelt.

Dels er det problematisk at anvende fortællinger til at udsige noget generelt om det, fortællingerne beretter om (Gunaratnam \& Oliviere, 2009). Her kræver det en udfoldelse af det almene ved det partikulære, før man kan hævde at have beskrevet noget, der kan overføres til andre kontekster. Dels er det nødvendigt at forholde sig kritisk til det konstruerede ved fortællinger, da der er tale om en gendigtning af virkeligheden fremfor en 1:1 beskrivelse. I det henseende er det vigtigt at stille spørgsmål til, hvem der tildeles udsigelseskraft i de fortællinger, der udvikles på baggrund af et empirisk materiale. Har forskerens perspektiv forrang? Eller integreres 'de andres' perspektiver, så fortællingen bliver til en metafortælling, om hvordan 'virkelighed' er udtryk for mange divergerende perspektiver?

Ved at afprøve genfortælling som metode, der sikrer en (mere) troværdig gengivelse af den mangfoldighed af perspektiver, som kvalitative undersøgelser har potentiale til at afdække, har jeg ved at inddrage en informant på et senere tidspunkt $\mathrm{i}$ formidlingsprocessen, genforhandlet den meningsdannende begivenhed, som empiriindsamlingen kan anses som. Jeg får med andre ord skabt en ny refleksionsmulighed på fremstillingsprocessen og skaber herigennem en ny fortælling. Den nye fortælling handler om den spænding, der eksisterer mellem de fortolkninger, som er indlejret i vores forskellige fortællinger om Marys liv og levned. Her er troværdigheden ved den oprindelige fortælling knyttet til at få denne spænding bragt frem. Det sker ved at fremhæve forskellene og beskrive de reaktioner, der følger af at konfronteres med andre af de involveredes fortællinger.

For at forstå hvordan det opleves at være døende gennem andres fortællinger, må man være sand overfor den overordnede fortælling, som de mindre fortæl- 
linger indgår i. Det betyder at konteksten for formidlingen af fortællingen bliver vigtig at medtage. For mit vedkommende bliver fortællingen skrevet ind i en forskningsmæssig sammenhæng, hvor den enten skal bekræfte eller udfordre eksisterende viden. For Otto handler det om at værne sit minde om Mary, mens det for niecen måske handler om at indfri sin families forventninger til, hvordan hun bedst kan beskrive sin moster. Uanset hvilket fortællerperspektiv, der medtages, udvider det 'den empiriske fortælling' og øger kompleksiteten. Det er derfor kompleksitetsgraden af en fortælling, der kan træde i stedet for en egentlig validering, da bestræbelse på at lade de involverede positioner træde tydeligt frem forøger muligheden for forståelse gennem at indleve sig i det, der med rette kan opfattes som 'en troværdig fortælling'.

\section{Noter}

${ }^{1}$ For klarhedens skyld kan man skelne mellem et narrativ og en fortælling, ved at et narrativ består af en sammenkædning af begivenheder, som man gennem den narrative struktur tilskriver en form for kausalitet, mens fortællinger indbefatter en større sammenhæng, som et handlingsforløb, personbeskrivelser og en tilsigtet emotionel reaktion på det beskrevne, hvorved narrativer anvendes som byggesten (Paley \& Eva, 2005).

\section{Referencer}

Boelsbjerg, H. B. (2017). At nærme sig døden-Menneskeligt og metodisk, en kvalitativ undersøgelse af kristne og muslimske kræftpatienter i palliative forløb, ph.d.-afhandling. Institut for Sundhedstjenesteforskning, Det Sundhedsfaglige Fakultet, Syddansk Universitet.

Charon, R., DasGupta, S., \& Hermann, N. (2017). The principles and practice of narrative medicine. Oxford University Press.

Glasdam, S., \& Øye, C. (2013). Alcohol abuse in cancer patients: A shadow side in the oncological field and research. Medicine, Health Care and Philosophy, 17(3), 437-446. https:// doi.org/10.1007/s11019-013-9541-x

Gunaratnam, Y., \& Oliviere, D. (2009). Narrative and stories, illness, dying and bereavement. Oxford University Press.

Hastrup, K., Rubow, C., \& Tjørnhøj-Thomsen, T. (2011). Kulturanalyse, kort fortalt (1. udgave). Samfundslitteratur.

Järvinen, M. (2000). Biographical illusion-Constructing meaning in qualitative interviews. Københavns Universitet ;

Juhl Rasmussen, A. (2017). Læse, skrive og hele, perspektiver på narrativ medicin. Syddansk Universitetsforlag. 
Mattingly, C. (2001). Healing dramas \& clinical plots. Narrative structure of experience. Cambridge UnivPress.

Paley, J., \& Eva, G. (2005). Narrative vigilance: The analysis of stories in health care. Nursing Philosophy, 6(2), 83-97. https://doi.org/10.1111/j.1466-769X.2005.00195.x 